\title{
Ecological and Structural Analyses of Trees in an Evergreen Lowland Congo Basin Forest
}

\author{
Romeo Ekoungoulou ${ }^{1}$, Donatien $\mathrm{Nzala}^{2}$, Xiaodong $\mathrm{Liu}^{1} \&$ Shukui $\mathrm{Niu}^{1}$ \\ ${ }^{1}$ Laboratory of Ecological Planning and Management, College of Forestry, Beijing Forestry University, Beijing \\ 100083, China \\ ${ }^{2}$ Département des Techniques Forestières, Ecole Nationale des Sciences Agronomiques et Forestières, Université \\ Marien Ngouabi, BP69 Brazzaville, Republic of Congo \\ Correspondence: Shukui Niu, Laboratory of Ecological Planning and Management, College of Forestry, Beijing \\ Forestry University, Beijing 100083, China. E-mail: niushukui@yahoo.com
}

Received: July 6, 2017

doi:10.5539/ijb.v10n1p31
Accepted: August 25, 2017

URL: https://doi.org/10.5539/ijb.v10n1p31

\begin{abstract}
Floristic inventory and diversity assessments are necessary to understand the present diversity status and conservation of forest biodiversity. Studying the variation height-diameter woody provides insight into the general characteristics of the trees diversity pattern. This study mainly focuses on aimed to assess the effectiveness of trees diversity and structure in two study sites. The study was conducted at Ipendja evergreen lowland moist forest in northern Republic of Congo. The sampling design was systematic consisted of parallel transect 1 or $2 \mathrm{~km}$ part, and divided into consecutive rectangular plots, each $5000 \mathrm{~m}^{2}(25 \times 200 \mathrm{~m}$, i.e. $0.5 \mathrm{ha})$. Within eight plots censuses, all trees with a DBH $\geq 10 \mathrm{~cm}$ were identified and measured. A total of 1340 trees has been recorded belonged 145 species and 36 families ( $n=607$ and $n=733$, respectively in Mokelimwaekili and Sombo sites). The results show that the leading botanical families were Sapotaceae follows by Euphorbiaceae, Meliaceae, Caesalpiniaceae, Sterculiaceae, Annonaceae and Rubiaceae. The most representative species were C. mildbraedii, S. kamerunensis and $P$. oliveri, i.e. $62.06 \%, 30.34 \%$ and $28.27 \%$ respectively, demonstrated that they were the leading dominant species of this forest ecosystem. Shannon index were 4.29 bits for Mokelimwaekili and 4.22 bits for Sombo. While Pielou's evenness index was between 0.88 and 0.90, respectively for the Mokelimwaekili and Sombo sites. The similarity coefficient for Jaccard was $62 \%$ and $58 \%$ for Sorensen. There are highlight variations in tree diversity indices across sites and plots in Ipendja forest.
\end{abstract}

Keywords: diversity, forest ecosystem, ipendja forest, mokelimwaekili, sombo, tree species

\section{Introduction}

The growing interest of policy makers in conservation and sustainable management of natural resources has led them to take legal law in favor of biodiversity (Folega et al., 2010). The law investment in the forestry sector, increasing population pressure and weak public institutions affect forestry resource management, deforestation and forest service quality, thus threatening the ecosystems (Folega et al., 2014; FAO, 2016). Sustainable forest management focuses on the sustainability of many forest products and services over long periods of time (Ouedraogo et al., 2011). Forests worldwide show pronounced biogeographical differences in structure, function and dynamics, which are, the varying degrees, linked to the heights of trees at a given site (Feldpausch et al., 2011; Thomas et al., 2015).

Tropical forests constitute the most diverse plant communities on earth (Supriya-Davi and Yadava, 2006; Ekoungoulou et al., 2014b; Fayolle et al., 2015; FAO, 2016). These forests are disappearing at alarming rates owing to deforestation for extraction of timber and other forests products (Supriya-Devi and Yadava, 2006; Ouedraogo et al., 2011; Ekoungoulou, 2014). In India shifting cultivation operation are most obvious causes of forests disturbances. The problem with the chronic form of forest disturbance is that plants or ecosystem often do not get time to recover adequately because the human onslaught never stops (Supriya-Devi and Yadava, 2006). The tropical climatic part of world had the highest decrease in forest area of any domain from 2000 to 2010, and it was the only domain to show an increase in agricultural area (FAO, 2016). An estimated 7 million hectares of forest was lost per year over the period in the tropics, and the area of agricultural land increased by six million hectares per year $(\mathrm{FAO}, 2016)$. Tropical forests are the subject of several studies to better understand the role they 
could play in sustainable development, climate change, and floristic biodiversity (Nasi et al., 2012; Koubouana et al., 2016; Ekoungoulou et al., 2017). However, Koubouana et al., (2016) demonstrated that tropical forests are characterized by high biodiversity; this diversity is an indicator that allows appreciating links between the richness and the abundance of individuals. It reflects the degree of heterogeneity or stability of vegetation.

Congo basin forests located in central Africa are the world's second largest tropical forest, after the Amazonian basin, with a wide plant species diversity, storing enormous carbon amounts and provide an irreplaceable source of ecological, social and economic services for local populations, states and the international community (Lewis et al., 2013; Ekoungoulou et al., 2015; Fayolle et al., 2016). Like the others, the Congo basin forests are confronted with global changes such as increased anthropogenic pressures (Logging, land conversion, mining), changes in the rainfall regime that risk in the near future to cause their degradation and fragmentation, and the partial or complete loss of the functions and services they perform today (FAO, 2016; STC, 2016).

Located in central Africa and crossed by the equator, the Republic of Congo with a total cover area of $342,000 \mathrm{~km}^{2}$, has vegetation made up with $65 \%$ of forests and $35 \%$ of savannas unequally distributed on the unit of the territory (Kimpouni et al., 2013; Ekoungoulou et al., 2017). The total forest cover of the Republic of Congo is around 22 million ha (Ekoungoulou et al., 2014a; STC, 2016). The forest cover of the northern part is around 16 million ha, and the south part of country has about 6 million ha (Koubouana et al., 2015; STC, 2016). However, among the two types of vegetation, there are savannas included in forest zone and the forest facies of low savannas area. The forest of the Patte d'Oie of Brazzaville is one of these witnesses. The forests of Republic of Congo and those studied by Ekoungoulou, (2014) on the Teke-Plateau are facies which one meets in the phytogeographical Pool province (Ekoungoulou et al., 2014b). The ombrophilous forests type of the Teke-plateau, evolve in wet bottoms funds and well drained valleys, whereas that of the Patte d'Oie develops on a lowland with psammitic substrate. Thus, it is presented under the aspect of a facies mesophyll dry typical and specific to Congo (Kimpouni et al., 2013).

The management of any resource needs to begin with an inventory of that resource (Ekoungoulou, 2014). Floristic inventory is a prerequisite for fundamental research in tropical community ecology, such as modeling patterns of species diversity or understanding species distributions (Folega et al., 2010; FAO, 2016). Floristic inventory and diversity studies help in understanding the species composition and diversity status of forests, which also offer vital information for forest conservation (Raunkier, 1934; Aubreville, 1968; Legendre, 2014; Ekoungoulou et al., 2017). Inventory help in identification of species that are in different stages of vulnerability as well as the various aspects that influence the existing vegetation in any region (Lopez-Gonzalez et al., 2011; Fedor and Spellerberg, 2013). Quantitative floristic sampling also provides necessary context for planning and interpreting long-term ecological research (Spellerberg and Fedor, 2003; Supriya-Devi \& Yadava, 2006). High rates of vertical growth allow trees to physically dominate over other plant growth forms where the environment is suitable. Ecological researches concerned with horizontal components of forest structure, such as stem density and basal area, have shown large scale variations along broad environmental and/or edaphic gradients (Feldpausch et al., 2011; Schluter and Pennell, 2017); however, variations in the vertical components of forest structure and their causes remain much less studied. This is despite available evidence suggesting that tree height, $\mathrm{H}$, for a given diameter (D) may vary significantly among species and across regions (Spellerberg and Fedor, 2003; Legendre, 2014). Such differences could hold important implications for carbon storage potential of tropical forests. This is because tropical tree aboveground biomass and carbon fluxes are recently estimated by using allometric models to diameter at breast height measurements only. Thus assuming a constant height-diameter $(H: D)$ ratio, stem taper and crown mass fraction (Feldpausch et al., 2011). From a phytogeographic point of view, White (1986) places the northern Republic of Congo in the regional Centre of Guineo-Congolese endemism and more precisely in the lower Guinean sub-Centre. Different types of vegetation, based on structural parameters and their botanical composition, are met within the Ipendja Forest Management Unit (UFA) in Republic of Congo (STC, 2016). These are mainly the following facies: terra firma Evergreen, Marantaceae forests, hydromorphic soil formations, and Gilbertiodendron dewevrei (De Wild.) J. Leonard monodominance forests. Aubreville, (1968) defines terra firma evergreen as Ulmaceae, Sterculiaceae (now included in Malvaceae), Caesalpiniaceae (now included in Fabaceae), Sapotaceae, and Meliaceae dense semi-deciduous forests. The canopy is more or less closed and the undergrowth is generally open. Theses forest types, defined in the classification of Atlantic central Africa forest type from Xycol (see www.xycol.net) as dense evergreen deciduous forests, are characterized by the relative abundance of Celtis mildbraedii Engl., Triplochiton scleroxylon K. Schum., Gambeya africana (A. DC.) Pierre, Piptadeniastrum africanum (Hook.f.) Brenan and Terminalia superba Engl. \& Diels.

Therefore, inventory and diversity studies are taken up at different levels all over the world by various research groups with available resources and to fill the gap in the biodiversity knowledge, there are variations in sampling 
methods/techniques, sample size, measurements taken in the field that hinder the compilation and comparison of results. The research was focused in areas of important biodiversity. The main objective of this study was to describe the old-growth and selective logging forests by analyzing the structures and diversity of tree species. The specific objectives of this study were (i) to analyze the species composition and stand structure of the different forest types, (ii) to compare the different forest types and explore their effectiveness in species with ecological conditions, and (iii) to analyze the variation height-diameter of trees inter-and-intra plot, inter-and-intra site.

\section{Material and Methods}

\subsection{Study Sites}

The sites, in which the experimental plots of this study have been installed in Likolomwaekili and Sombo sites in Ipendja UFA (Forest Management Unit), were located in the Likouala $\left(1^{\circ} 38^{\prime} \mathrm{N}, 18^{\circ} 04^{\prime} \mathrm{E}\right)$ area. Likouala is a department of the Republic of Congo (Central Africa), in the northern part of the country. It borders the departments of Cuvette and Sangha, and internationally, the Democratic Republic of Congo and the Central African Republic. The region (department) has an area of $66,044 \mathrm{~km}^{2}$ and an estimated population of almost 90,000 (STC, 2016). The chief town is Impfondo. Principal cities and districts include Epena and Dongou. Likouala currently occupies the first place in the production of Congo's wood. Historically, this department (Province) was cut off from part of Lobaye, an area of the Central African Republic. It is believed that it was first inhabited by the Pygmy tribe. However, Likouala is almost covered with dense and often flooded forests of lakes and very full of fish ponds. Its ground is argillaceous and sandy by places (STC, 2016). The north of Likouala department belongs to the mountainous Oubanguian Massif. The shallow Tele Lake is $5 \mathrm{~km}$ across and circular in shape. Populations of Likouala would have come from North, the South, the East and the West. Pygmies peoples are regarded as the first occupants of this ground. The department counts many Rwandan, Central African Republic refugees and people from Democratic Republic of Congo. Six forest management units (UFA) are in the course of logging by several companies, of which Processing industry of Likouala forest's timber (ITBL), Thanry-Congo logging company and Likouala-Timber. Likouala area has a tropical climate (ANAC, 2016). The dry season is from March to July, the remainder of the year being dominated by the rainfall season. Our study area named Ipendja $\left(\mathrm{N} 02^{\circ} 32, \mathrm{E}^{017^{\circ} 09}\right.$; N02 $\left.39, \mathrm{E} 017^{\circ} 20\right)$ is located in Dongou district (Likouala department in Northern Republic of Congo). Ipendja forest management unit is managed by the Thanry-Congo logging company. Thanry-Congo Company is one of forest concessions based in Republic of Congo for logging with a reduced impact. Two sites have been studied, such as Mokelimwaekili (4 plots) and Sombo (4 plots) (Figure1). Distance between Mokelimwaekili site and Sombo site is around $25 \mathrm{~km}$ (STC, 2016). Ipendja have been described as a tropical lowland evergreen forest (Aubreville, 1968; STC, 2016). The annual rainfall is up to $1800 \mathrm{~mm}$ with a distinct dry season from December to February. The mean annual variation in temperatures is from $20^{\circ}$ to $25^{\circ} \mathrm{C}$ (ANAC, 2016).

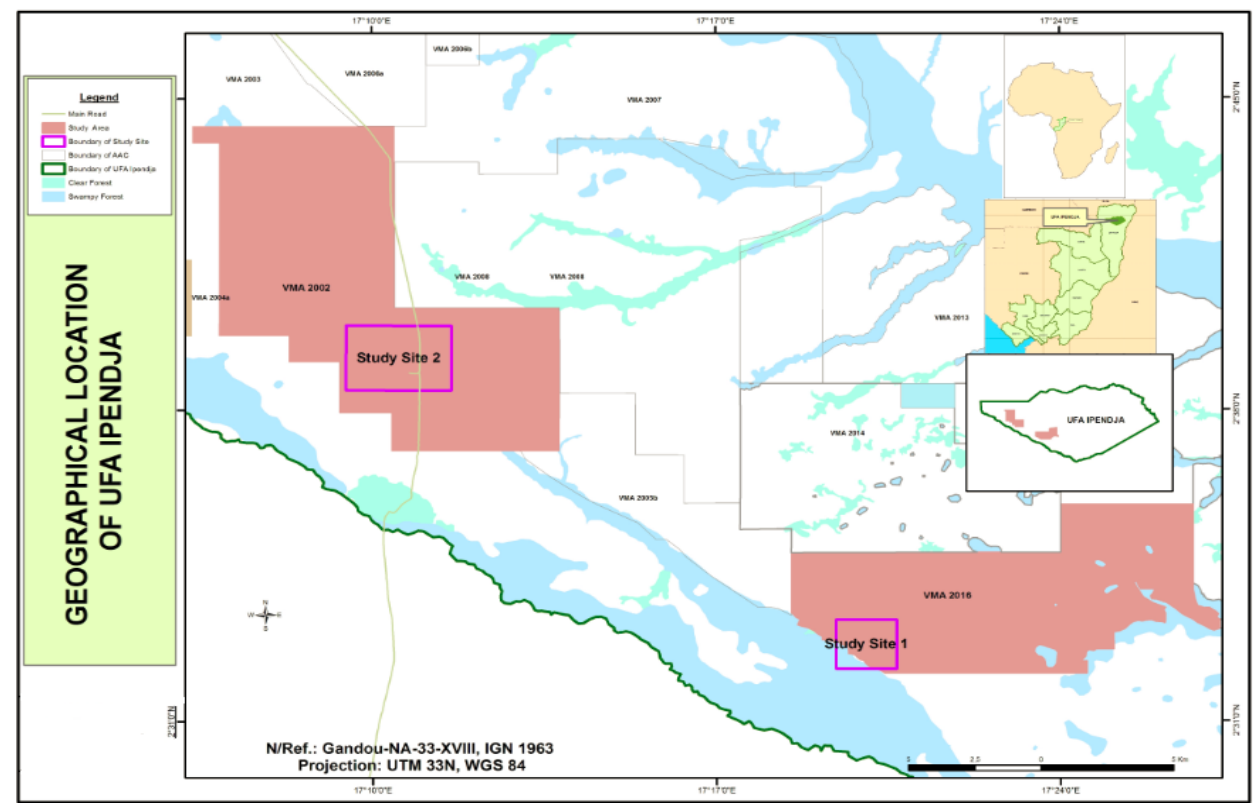

Figure 1. Survey areas Location. Site1 is Mokelimwaekili and Site2 is Sombo. 


\subsection{Data collection}

The field measurements were based on techniques using rectangular plots, each $5000 \mathrm{~m}^{2}(25 \times 200 \mathrm{~m}$, i.e $0.5 \mathrm{ha})$. The study had retained 8 rectangular plots each separated by roughly $1 \mathrm{~km}$. All 8 plots inventoried were divided into 2 sites, such as Mokelimwaekili (4 plots) and Sombo (4 plots). Tree measurements have been conduct on plots with a slope $<5^{\circ}$ (almost flat). Also, measurements have been making solely on the trees $\mathrm{DBH} \geq 10 \mathrm{~cm}$, at $1.3 \mathrm{~m}$ height, and only these were marked with a nail and polyvinyl chloride (PVC) plastic label (Lopez-Gonzalez et al., 2011). Trees have been measured using the criteria of diameter at breast height measurements $(\mathrm{DBH} \geq 10 \mathrm{~cm})$ because the stand age of the forest in the study area was not particularly young. Also, Ipendja forest is a tropical evergreen lowland terra firma forest with a status of old-growth (Mokelimwaekili) and selective logging (Sombo) forests. The stems less than $10 \mathrm{~cm}$ would normally be measured in fairly young forest. We then had used a compass (model SILVA-2S, Scale 1:24000) to determine cardinal points (N-S \& E-W) or orientations of each plot. A forestry tape (model Forestry Pro) help us to measure diameter at breast height of trees and a hypsometer (brand Nikon, Forestry Pro, waterproof $6 \times 216.0^{\circ}$, model: Laser WJ072214) was used to measure height of trees in each plot. Finally, a GPS (model Garmin 62CSx) to record the plot coordinates (location) in minutes, degrees and seconds has been used. GPS points were then recorded in each plot center. Fieldwork has been performed according to AfriTRON (See www.afritron.org) and Forest plots (See www.forestplots.net) protocols.

\subsection{Data Analysis}

The general checklist of species composing the flora procession has been established after digital processing of eight sample plots. On the basis of The African plants database (version 3.4.0) of Conservatoire et Jardin botaniques de la ville de Geneve, Switzerland \& South African National Biodiversity Institute, Pretoria (accessed 20 October 2016 at http://www.ville-ge.ch/musinfo/bd/cjb/africa/recherche.php), The Global plants database (accessed on 10 January 2017 at http://plants.jstor.org, The working list of all plant species database (retrieved 16 February 2017 from http://www.theplantlist.org), and The Xycol database (The list of scientific and vernacular woods names: accessed on 26 October 2016 at http://www.xycol.net/inde x.php?categorie $=0 \&$ sess_langue $=430$ ). A diversity index is a quantitative measure that reflects how many different species there are in a community, and simultaneously take into account how evenly the basic entities (such as individuals) are distributed among those types. For each studied site, diversity indices such as: species richness, Shannon index (Eq. 1), Pielou's everness (Eq. 2), Jaccard and Sørensen similarities (Eq. 3 \& Eq. 4), relative species frequency (Eq. 5) and Importance value index (Eq. 6) were calculated to deduce information regarding the species distribution. To determine the dominance, basal area has been calculated (Eq. 7). The following formulas have been used to calculate theses indices:

\subsubsection{Shannon-Wiener Diversity Index $\left(\mathrm{H}^{\prime}\right)$}

The Shannon-wiener index of species diversity is one of many indices of species diversity and is one based on the concept of evenness such as the extent to which each species is represented among a sample (Fedor and Spellerberg, 2013). Shannon-wiener diversity index is an index that is not greatly affected by sample size (Spellerberg and Fedor, 2003). The Shannon-wiener index has been calculated as follows:

$$
H^{\prime}=-\sum_{i=1}^{n}\left(\left(N_{i} / N\right) * \log _{2}\left(N_{i} / N\right)\right)
$$

With accordance to Shannon-wiener index: $\boldsymbol{H}^{\prime}$ is the Shannon-Wiener index of species diversity, $\boldsymbol{N} \boldsymbol{i}$ is the number of samples in which the species $\boldsymbol{i}$ was present, $\boldsymbol{\Sigma}$ is the sum of the calculations, $\boldsymbol{n}$ is the number of species and $\boldsymbol{N}$ is the total number of samples.

\subsubsection{Pielou's Evenness Index (E)}

Species evenness refers to how close in numbers each species in an environment is. Mathematically it is defined as a diversity index, a measure of biodiversity which quantifies how equal the community is not very even. But if there are 20 foxes and 22 dogs, the community is quite even. The Pielou's evenness index has been expressed by:

$$
E=\frac{H^{\prime}}{H^{\prime} \text { max }}=-\frac{\sum_{i=1}^{n}\left(\left(N_{i} / N\right) * \log _{2}\left(N_{i} / N\right)\right)}{\log _{2}(n)}
$$

Where $\boldsymbol{E}$ is evenness index of Pielou, $\boldsymbol{H}^{\prime}$ is the number of derived from the Shannon diversity index, $\boldsymbol{n}$ is the total number of species, $\boldsymbol{N i}$ is the number of samples in which the species $\boldsymbol{i}$ was present, $\boldsymbol{N}$ is the total number of samples, and $\boldsymbol{H}^{\prime}{ }_{\text {max }}$ is the maximum possible value of $\boldsymbol{H}^{\prime}$ (if every species was equally likely). $\boldsymbol{E}$ is constrained between 0 and 1 . The less evenness in communities between the species (and the presence of a dominant species), the lower evenness is, and vice versa. 


\subsubsection{Similarity Coefficient of Jaccard (J)}

The Jaccard similarity coefficient is known as intersection over union and the Jaccard similarity coefficient is a statistic used for comparing the similarity and diversity of study sample. The Jaccard coefficient measures similarity between finite sample sets, and is defined as the size of the intersection divided by the size of the union of the sample sets. Jaccard similarity was calculated using the following formula:

$$
J=100 * \frac{c}{a+b-c}
$$

Where $\mathrm{a}$ is the number of species in community $\mathrm{A}, \mathrm{b}$ is number of species in community $\mathrm{B}$, while $\mathrm{c}$ is the number of species common to both communities.

\subsubsection{Similarity Coefficient of Sørensen (K)}

The similarity coefficient of Sørensen is distinguishable by the fact that the first gives the same rating to presence and absence, whilst the second grants a double benefit to the presence. In this latter case, the presence is more informative than the absence (Legendre, 2014).

$$
K=\frac{2 C}{A+B} * 100
$$

Where $\mathrm{A}$ is the number of species of the first census, $\mathrm{B}$ is the number of species of the second census, $\mathrm{C}$ is the number of species common to both censuses.

\subsubsection{Relative Frequency (F)}

The relative frequency and specific contribution of each tree species and family have been performed as follows:

$$
F_{(\%)}=\frac{n_{i}}{N} \times 100
$$

Where $\boldsymbol{F}$ is relative frequency of species and family (in \%), $\boldsymbol{n} \boldsymbol{i}$ is the number of individual $\boldsymbol{i}$ and $\boldsymbol{N}$ is the total number of individuals found in the communities.

\subsubsection{Species Richness (SR)}

Species richness is the number of different species represented in ecological community. It's the simply a count of species, and it does take into account the abundances of the species or their relative abundance distributions. Species richness has been used as a criterion when assessing the relative diversity values of habitats. Therefore, species richness is blind to the identity of the species.

\subsubsection{Importance Value Index (IVI)}

The importance value index (IVI) for the tree species was determined as the sum of the relative density, relative frequency and relative dominance (Curtis, 1959; Liu et al., 2009).

$$
\text { IVI }=\text { Fri } * \text { Densri } * \text { Domri } * 100
$$

Where Fri is species relative frequency, Densri is species relative density and Domri is species relative dominance.

The ratio of abundance to frequency for different species was determined for eliciting the distribution patterns (Supriya-Devi \& Yadava, 2006).

\subsubsection{Basal Area (BA)}

Basal area is the area of a given section of land that is occupied by the cross-section of tree trunks and stems at the base (Feldpausch et al., 2011; Ekoungoulou, 2014; Folega et al., 2014; Fayolle et al., 2016). Measurement taken at the diameter at breast height $(1.3 \mathrm{~m})$ of tree above the ground and include the complete of every tree, including the bark (Lopez-Gonzalez et al., 2011). Measurements have been made for plots and this is then scaled up for one hectare of land for comparison purposes to examine a forest's productivity rate.

Stand level basal area (BA) for each census was calculated as:

$$
B A=\frac{\left(\sum n \pi *\left(\frac{D_{i}}{2}\right)^{2}\right)}{h a}
$$

Where $B A$ is Basal area $\left(\mathrm{m}^{2} \mathrm{ha}^{-1}\right), D i$ is the diameter at breast height of tree $i$ at $1.3 \mathrm{~m}$ above the ground (in $\left.\mathrm{cm}\right), \pi$ is 3.14 and $n$ is the number of stems per plot.

Data analysis has been performed using SPSS v.18.0, SigmaPlot v.10.0, PAST v.3.05 and ArcGIS v.9.3 softwares. 


\section{Results}

\subsection{Forest Trees Diversity Overview}

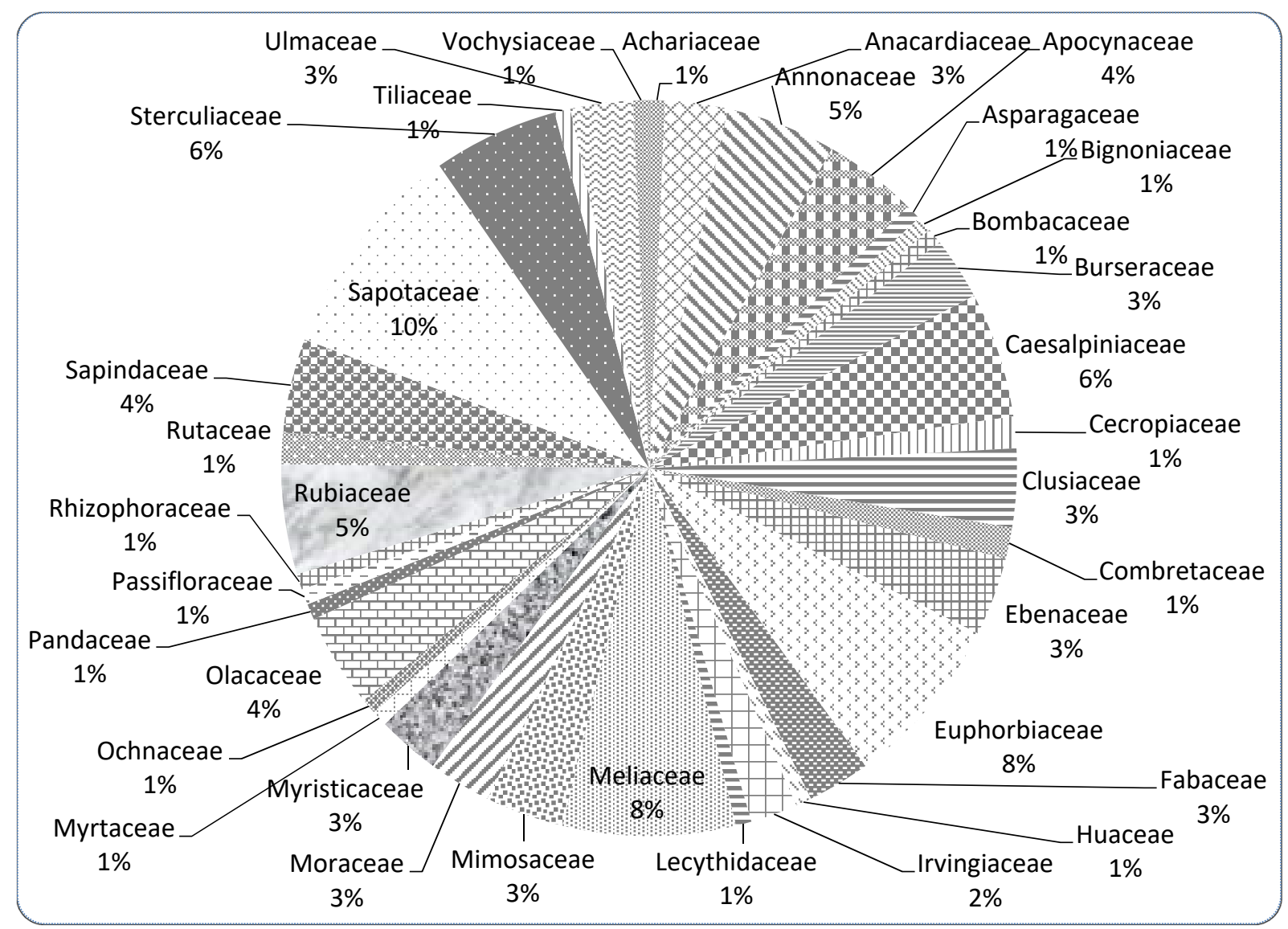

Figure 2. Families specific spectra

The investigation revealed a total number of 1340 trees of DBH $\geq 10 \mathrm{~cm}$ in the study sites have been recorded. These trees belonged to 36 families and 145 species. The representative families with at least around $3 \%$ of taxon diversity were: Sapotaceae (10\%), Euphorbiaceae (8\%), Meliaceae $(8 \%)$, Caesalpiniaceae $(6 \%)$, Sterculiaceae $(6 \%)$, Annonaceae (5\%), Rubiaceae (5\%), Apocynaceae (4\%), Olacaceae (4\%), Sapindaceae (4\%), Clusiaceae $(3 \%)$, Ebenaceae $(3 \%)$ and Mimosaceae $(3 \%)$ as asserted in Figure 2. Vochysiaceae (1\%), Tiliaceae (1\%), Rhizophoraceae (1\%), Passifloraceae (1\%), Pandaceae (1\%) and Ochnaceae (1\%) had a low relative frequency index. The most represented species in study area with height relative diversity index were Celtis mildbraedii Engl. (62.06\%), followed by Staudtia kamerunensis (Warb.) Fouilloy (30.34\%), Polyalthia oliveri Engl. with 90 individuals (28.27\%), Strombosia grandifolia Hook. f. ex Benth. (25.51\%), Garcinia atroviridis Griff. Ex T. Anderson (24.82\%), Petersianthus macrocarpus (P.Beauv.) Liben (24.13\%), Gambeya africana (A. DC.) Pierre (23.44\%), Guarea thompsonii Sprague \& Hutch. (23.44\%), and Carapa procera DC. (21.37\%). The less represented species were Zanthoxylum gilletii (De Wild.) P.G. Waterman (2.06\%), followed by Gilbertiodendron dewevrei (De Wild.) J. Leonard (1.37\%), and Cola acuminata (P. Beauv.) Schott \& Endl. (0.68\%) (Figure 2). In 145 species of study area, we recorded 90 common species (Figure 4a).

A total of 1340 trees were divided into two studied sites, respectively Mokelimwaekili (site1, $n=607$ ) and Sombo (site1, $n=733)$. Trees from Mokelimwaekili site $(n=607)$ are grouped into 34 families and 127 species. Trees from Sombo site $(n=733)$ are grouped into 33 families and 109 species. Plot1, Plot2, Plot3 and Plot4 are in Mokelimwaekili site and Plot5, Plot6, Plot7 and Plot8 are in Sombo site. Sapotaceae (12 species), Euphorbiaceae (10 species), Meliaceae (10 species) and Caesalpiniaceae (9 species) were the leading families in study site1. Meliaceae (10 species), Sapotaceae (10 species), Euphorbiaceae ( 9 species) and Annonaceae ( 9 species) were the leading families in study site2 (Figure 2). While Tiliaceae (1 species), Rhizophoraceae (1 species), Passifloraceae ( 1 species), Pandaceae (1 species) were the poorly represented in both of sites (Ipendja forest). 
In 127 species recorded at Mokelimwaekili, the most abundant were Celtis mildbraedii Engl. (54 individuals), followed by Guarea thompsonii Sprague \& Hutch. (20 individuals), Petersianthus macrocarpus (P.Beauv.) Liben (20 individuals), Polyalthia oliveri Engl. (20 individuals), Staudtia kamerunensis (Warb.) Fouilloy (20 individuals), Caloncoba mannii (Oliv.) Gilg (19 individuals), Celtis tessmannii Rendle (18 individuals), Pycnanthus angolensis (Welw.) Warb. (16 individuals), Strombosia grandifolia Hook. f. ex Benth. (18 individuals), and Nesogordonia kabingaensis (K.Schum.) Capuron ex R. Germ. (14 individuals). While in Sombo (109 species recorded), the most abundant species were Celtis mildbraedii Engl. (36 individuals), followed by Garcinia atroviridis Griff. ex T. Anderson (33 individuals), Gambeya beguei (Aubrev. \& Pellegr.) (24 individuals), Staudtia kamerunensis (Warb.) Fouilloy (24 individuals), Angylocalyx pynaertii De Wild. (22 individuals), Gambeya africana (A. DC.) Pierre (22 individuals), Polyalthia oliveri Engl. (21 individuals), Strombosia grandifolia Hook. f. ex Benth. (21 individuals), and Carapa procera DC. (20 individuals).

\subsection{Variation of Shannon and Pielou Indices}

Species diversity analysis has been performed also by considering the Shannon-wiener index. We have included in this study the analysis of tree diversity between sites. The result shows that the number of families and species varies from one site to another. Shannon-wiener index of species diversity were 4.29 bits for Mokelimwaekili and 4.22 bits for Sombo (Figure 3b). But Pielou's evenness indices were between 0.88 and 0.90, respectively for the Mokelimwaekili and Sombo sites (Figure 3a).

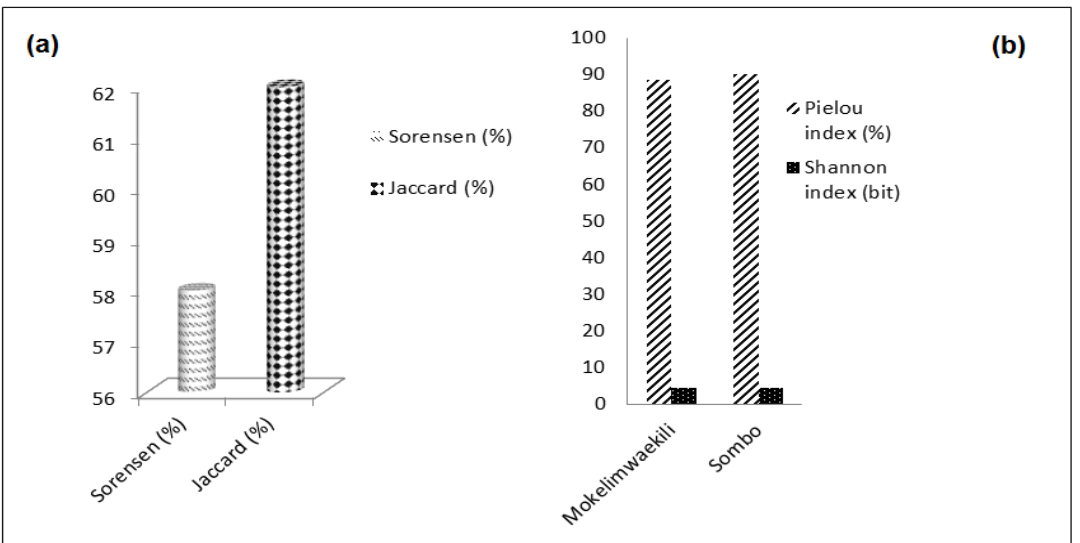

Figure3. Variation of Jaccard and Sørensen similarity coefficient between sites (a). Values of Shannon-wiener index of species diversity and Pielou evenness index (b)

\subsection{Similarity Coefficients Analysis of Jaccard and Sørensen}

Similarity among forest sites using the Jaccard similarity index showed that the Mokelimwaekili and Sombo, had 62 percent of the species in common and 58 percent for Sørensen similarity coefficient in the study sites. The values of Jaccard and Sorensen indices are greater than 55\%, determine a similarity between inventoried sites. But this similarity cannot hide the local flora distribution or variations. Figure 3 shows that in the 145 species of study area, there are 90 common species. In Mokelimwaekili we recorded 38 common species (29.92\%) and in Sombo we recorded 19 common species (17.43\%). Theoretically, inter-site heterogeneity would arise intra-site heterogeneity. To test this hypothesis, we performed a principal component analysis on the basis of an array of presence-absence of species on each site's distance. Obviously, it's interesting to a principal component analysis in the sites where there were more than two pas inventoried plots. However, there are variations in tree diversity indices across sites and plots in Ipendja terra firma forest (Table 2).

\subsection{Important Value Index (IVI) Distribution}

The important value index (IVI) computation applied to the 145 trees species of the study area showed that $C$. mildbraedii (62.06\%), S. kamerunensis (30.34\%), P. oliveri $(28.27 \%), S$. grandifolia $(25.51 \%)$ and $P$. macrocarpus (24.13\%) were the most important tree species of woody flora procession regarding Ipendja lowland terra firma forest. The importance value index (IVI) highlighted the important tree species which evolved in Mokelimwaekili and Sombo. The high importance value of C. mildbraedii and S. kamerunensis were well in line with their indicator values according to which the plant groupings were determined. Carapa procera DC. 
(Meliaceae) which is called Bopessi (Pygmy name) or Crabwood (commercial name), has been founded in Plot1, Plot2, Plot3, Plot4, Plot5, Plot6, Plot7, Plot8 and with a relative diversity frequency of $21.37 \%$. In Southern Republic of Congo (Congolese littoral), this Carapa procera has been recorded with a relative diversity frequency of 7.4\% (Kimpouni et al., 2008).

\subsection{Basal Area Distribution in the Study Area}

Basal area is one of the chief characteristics to determine dominance. So, relative dominance was determined as the relative value of basal area. The basal area of a tree stem was calculated from a tree diameter measurement (DBH) by assuming that the tree stem is perfectly circular and the base of the tree has the same diameter as the stem at $1.3 \mathrm{~m}$ above ground height for DBH measurement. The area of a circle is calculated by the formula $A=$ $\pi r^{2}$. DBH has been measured from diameter at breast height (DBH) and its basal area was calculated. Basal area provided better measure for the relative importance of species than simple stem count. It was obvious that basal area in plot4 $\left(32.41 \mathrm{~m}^{2} \mathrm{ha}^{-1}\right)$ were higher, follow by plot2 $\left(30.98 \mathrm{~m}^{2} \mathrm{ha}^{-1}\right)$, and plot1 with $28.93 \mathrm{~m}^{2} \mathrm{ha}^{-1}($ Table 1$)$. The lower basal area were recorded in plot6 $\left(21.63 \mathrm{~m}^{2} \mathrm{ha}^{-1}\right)$, follows by plot8 $\left(22.75 \mathrm{~m}^{2} \mathrm{ha}^{-1}\right)$, and plot5 with 23.48 $\mathrm{m}^{2} \mathrm{ha}^{-1}$ (Table1). Therefore, Basal area of Mokelimwaekili was higher compared with Sombo considering plot by plot and in average of survey sites. However, Sombo forest in plot8 presented low density compared with the seven other plots. Its basal area $\left(22.75 \mathrm{~m}^{2} \mathrm{ha}^{-1}\right)$ was lower than that of plot2. Average of basal area in Mokelimwaekili (29.64 $\left.\mathrm{m}^{2} \mathrm{ha}^{-1}\right)$ was higher than those of Sombo $\left(23.83 \mathrm{~m}^{2} \mathrm{ha}^{-1}\right)$.

\subsection{Between-Site Variation in Forest Structure}

It was clear that dendrometric parameters such as average height and average diameter in Mokelimwaekili were higher than those of Sombo (Figure 4b). According to the diameter at breast height (DBH) measurements, the result shows that most of trees with great DBH were founded in Mokelimwaekili (Figure $4 \&$ Table 1). It obvious that the heights of trees recorded in Mokelimwaekili were higher than those of Sombo (Table1). It showed that in this forest ecosystem, most of trees which have higher diameter were the trees with important height (Table 2). There are clearly variation between plots and sites regarding DBH in Ipendja forest (Figure 2b). There are highlight that height of trees in Mokelimwaekili were important compared with Sombo (Table 1).

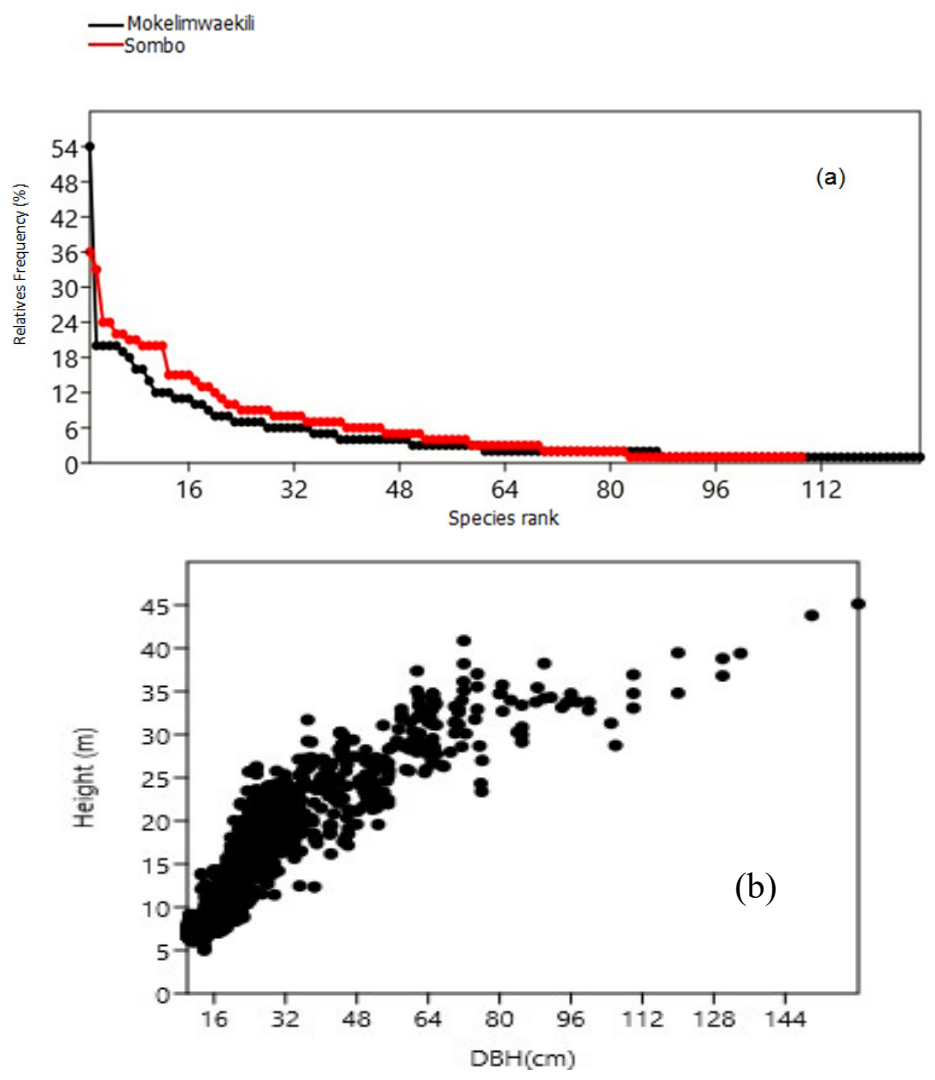

Figure4. Distribution of trees species in Mokelimwaekili and Sombo sites (a). It was obvious that the number of species founded in Mokelimwaekili were higher than those of Sombo. While the number of trees recorded in Sombo were higher than those of Mokelimwaekili. Height-diameter relationship of trees in forest ecosystem of Ipendja (b) 
Table 1. Diversity features of the various forest communities in this study. DBH: Average of diameter at breast height (in cm); SL: Selective logging performed in this area from 2002 to 2003 by one stem per hectare; BA: Basal area (in $\mathrm{m}^{2}$ ha ${ }^{-1}$ ); S: Number of species; $n$ : Number of sampled trees by site; Altitude: in meter; Height: Average height of trees (in $\mathrm{m}$ )

\begin{tabular}{|c|c|c|c|c|c|c|c|c|c|c|}
\hline \multirow[b]{2}{*}{ Plots } & \multirow[b]{2}{*}{$n$} & \multirow[b]{2}{*}{$\mathrm{S}$} & \multicolumn{2}{|c|}{ Dendrological data } & \multirow[b]{2}{*}{ BA } & \multirow[b]{2}{*}{ Site } & \multirow[b]{2}{*}{ Forest status } & \multicolumn{3}{|c|}{ GPS data } \\
\hline & & & DBH & Height & & & & Altitude & Latitude & Longitude \\
\hline Plot1 & 137 & 68 & 30.33 & 21.04 & 28.93 & Mokelimwaekili & Old-growth & 397 & ${\mathrm{~N} 02^{\circ} 32.889^{\prime}}^{\prime}$ & E017ㅇ․․ \\
\hline Plot2 & 187 & 73 & 25.53 & 14.42 & 30.98 & Mokelimwaekili & Old-growth & 385 & $\mathrm{~N} 02^{\circ} 22.744^{\prime}$ & 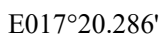 \\
\hline Plot3 & 134 & 61 & 28.38 & 14.83 & 26.24 & Mokelimwaekili & Old-growth & 385 & $\mathrm{~N} 02^{\circ} 32.340^{\prime}$ & 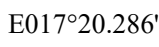 \\
\hline Plot4 & 149 & 58 & 29.24 & 15.92 & 32.41 & Mokelimwaekili & Old-growth & 390 & $\mathrm{~N}^{\prime} 2^{\circ} 33.170^{\prime}$ & $\mathrm{E} 017^{\circ} 19.636^{\prime}$ \\
\hline Plot5 & 171 & 64 & 25.51 & 12.22 & 23.48 & Sombo & SL & 378 & 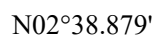 & $\mathrm{E} 017^{\circ} 10.163^{\prime}$ \\
\hline Plot6 & 184 & 70 & 22.69 & 12.75 & 21.63 & Sombo & SL & 383 & N02 $39.128^{\prime}$ & E017 $09.745^{\prime}$ \\
\hline Plot7 & 189 & 66 & 25.01 & 13.42 & 27.45 & Sombo & SL & 377 & $\mathrm{~N} 02^{\circ} 39.620^{\prime}$ & $\mathrm{E} 017^{\circ} 11.094^{\prime}$ \\
\hline Plot8 & 189 & 55 & 22.44 & 11.92 & 22.75 & Sombo & SL & 384 & $\mathrm{~N} 02^{\circ} 39.315^{\prime}$ & $\mathrm{E} 017^{\circ} 10.212$ \\
\hline
\end{tabular}

Table 2. Distribution of focal species recorded in the mixed evergreen lowland terra firma forest of Ipendja (study area) by family. Trees taxonomy was homogenized according to the African plants database (version 3.4.0) from Conservatory and botanic garden of Geneva, Switzerland \& South African National Biodiversity Institute, Pretoria (accessed 20 October 2016 at http://www.ville-ge.ch/musinfo/bd/cjb/africa/recherche.php), and Xycol database (The list of scientific and vernacular woods names: accessed 26 October 2016 at http://www.xycol. net/index.p hp?categorie $=0 \&$ sess_langue=430). DBH: Average of diameter at breast height for each species in study area (in $\mathrm{cm}$ ); P: Plot which species has been founded; $n$ : Number of individuals for each species recorded in Ipendja forest; Height: Average height of each species in study area (in m)

\begin{tabular}{|c|c|c|c|c|c|c|c|}
\hline Species & Family & Pygmy name & Commercial name & $n$ & DBH & Height & Plots \\
\hline Albizia adianthifolia (Schumach.) W. Wight & Mimosaceae & Ebaka & Mepepe & 13 & 41.18 & 19.17 & P7,P6,P7 \\
\hline Angylocalyx pynaertii De Wild. & Fabaceae & Mandjombe & Angylocalyx & 23 & 13.62 & 8.5 & P8,P3,P6,P5 \\
\hline Anonidium mannii (Oliv.) Engl. \& Diels & Annonaceae & Mobey & Ebom & 20 & 31.36 & 14.53 & $\mathrm{P} 8, \mathrm{P} 6, \mathrm{P} 5, \mathrm{P} 4, \mathrm{P} 3, \mathrm{P} 2, \mathrm{P} 1$ \\
\hline Blighia unijugata Baker & Sapindaceae & Blighia & Blighial & 10 & 43.23 & 22.11 & $\mathrm{P} 8, \mathrm{P} 4, \mathrm{P} 3$ \\
\hline Caloncoba mannii (Oliv.) Gilg & Achariaceae & Kouatolo & Caloncoba & 23 & 14.7 & 8.9 & P8,P7,P6,P4,P3,P2,P1 \\
\hline Carapa procera DC. & Meliaceae & Bopessi & Crabwood & 31 & 14.42 & 7.6 & $\mathrm{P} 8, \mathrm{P} 7, \mathrm{P} 6, \mathrm{P} 5, \mathrm{P} 4, \mathrm{P} 3, \mathrm{P} 2, \mathrm{P} 1$ \\
\hline Celtis mildbraedii Engl. & Ulmaceae & Ngombe & Ohia & 90 & 24.76 & 14.34 & $\mathrm{P} 8, \mathrm{P} 7, \mathrm{P} 6, \mathrm{P} 5, \mathrm{P} 4, \mathrm{P} 3, \mathrm{P} 2, \mathrm{P} 1$ \\
\hline Celtis tessmannii Rendle & Ulmaceae & Ekekiele & Diania & 27 & 33.33 & 17.12 & P8,P7,P5,P4,P3,P2,P1 \\
\hline Coelocaryon botryoides Vermoesen & Myristicaceae & Ebondo & Ekoune2 & 18 & 23.81 & 16.68 & $\mathrm{P} 7, \mathrm{P} 6, \mathrm{P} 5, \mathrm{P} 4, \mathrm{P} 3, \mathrm{P} 2$ \\
\hline Coelocaryon preussii Warb. & Myristicaceae & Dissako & Ekoune1 & 13 & 15.47 & 10.33 & P8,P7,P6,P4,P3,P2 \\
\hline Corynanthe pachyceras $\mathrm{K}$. Schum & Rubiaceae & Kania & Kangue & 10 & 33.09 & 21.77 & $\mathrm{P} 8, \mathrm{P} 7, \mathrm{P} 5, \mathrm{P} 4, \mathrm{P} 2, \mathrm{P} 1$ \\
\hline Dacryodes pubescens (Vermoesen) H.J. Lam & Burseraceae & Musafousafou & Safoukala & 16 & 21.1 & 12.32 & $\mathrm{P} 8, \mathrm{P} 7, \mathrm{P} 6, \mathrm{P} 5, \mathrm{P} 3, \mathrm{P} 2$ \\
\hline Dialium dinklagei Harms & Caesalpiniaceae & Mbasso & Eyoum3 & 13 & 24.96 & 14.11 & $\mathrm{P} 8, \mathrm{P} 7, \mathrm{P} 6, \mathrm{P} 4, \mathrm{P} 3, \mathrm{P} 2, \mathrm{P} 1$ \\
\hline Dialium pachyphyllum Harms & Caesalpiniaceae & Mbasso & Eyoum1 & 10 & 15.56 & 8.8 & $\mathrm{P} 8, \mathrm{P} 7, \mathrm{P} 6, \mathrm{P} 4, \mathrm{P} 3$ \\
\hline Diospyros perrieri (Hiern) Jumelle & Ebenaceae & Nzete ya mino & Ebene5 & 15 & 14.86 & 7.8 & $\mathrm{P} 7, \mathrm{P} 6, \mathrm{P} 5, \mathrm{P} 4, \mathrm{P} 3$ \\
\hline Duboscia macrocarpa Bocp. & Tiliaceae & Ekaka & Akak & 23 & 30.32 & 16.99 & $\mathrm{P} 8, \mathrm{P} 7, \mathrm{P} 6, \mathrm{P} 5, \mathrm{P} 4, \mathrm{P} 3, \mathrm{P} 2$ \\
\hline Entandrophragma angolense (Welw.ex C. DC.) C. DC. & Meliaceae & Diboyo & Sapeli & 14 & 62.08 & 22.66 & $\mathrm{P} 3, \mathrm{P} 7, \mathrm{P} 5, \mathrm{P} 4, \mathrm{P} 3, \mathrm{P} 1$ \\
\hline Eribroma oblonga (Mast.) Pierre ex A. Chev. & Sterculiaceae & Gboyo & Eyong & 11 & 35.27 & 20 & $\mathrm{P} 6, \mathrm{P} 5, \mathrm{P} 3, \mathrm{P} 1$ \\
\hline Funtumia africana (Benth.) Stapf & Apocynaceae & Ndembo & Dembo & 14 & 23.82 & 14.05 & $\mathrm{P} 8, \mathrm{P} 7, \mathrm{P} 6, \mathrm{P} 4, \mathrm{P} 2, \mathrm{P} 1$ \\
\hline Gambeya africana (A. DC.) Pierre & Sapotaceae & Bobambu & Longhi rouge & 34 & 28.93 & 16.5 & $\mathrm{P} 8, \mathrm{P} 7, \mathrm{P} 6, \mathrm{P} 5, \mathrm{P} 4, \mathrm{P} 3, \mathrm{P} 2, \mathrm{P} 1$ \\
\hline Gambeya beguei (Aubrev. \& Pellegr.) & Sapotaceae & Monopi & Longhi blanc & 26 & 22.86 & 11.86 & $\mathrm{P} 7, \mathrm{P} 6, \mathrm{P} 5, \mathrm{P} 3, \mathrm{P} 1$ \\
\hline Gambeya subnuda (Baker) Pierre & Sapotaceae & Meleku & Longhi2 & 10 & 20.79 & 12.68 & $\mathrm{P} 5, \mathrm{P} 4, \mathrm{P} 3, \mathrm{P} 2, \mathrm{P} 1$ \\
\hline Ganophyllum giganteum (A.Cheval.) Haumann & Sapindaceae & Ekomou & Mokenjo & 14 & 14.56 & 8.5 & $\mathrm{P} 6, \mathrm{P} 5, \mathrm{P} 4, \mathrm{P} 2, \mathrm{P} 1$ \\
\hline Garcinia atroviridis Griff. ex T. Anderson & Clusiaceae & Mokata & Garcinia & 36 & 17.21 & 10.2 & $\mathrm{P} 8, \mathrm{P} 7, \mathrm{P} 6, \mathrm{P} 5, \mathrm{P} 4$ \\
\hline Guarea thompsonii Sprague \& Hutch. & Meliaceae & Mbenia & Bosse fonce & 34 & 19.61 & 10.08 & $\mathrm{P} 8, \mathrm{P} 6, \mathrm{P} 5, \mathrm{P} 4, \mathrm{P} 3, \mathrm{P} 2, \mathrm{P} 1$ \\
\hline Khaya anthotheca (Welw.) C. DC. & Meliaceae & Deke & Acajou & 14 & 24.99 & 12.27 & $\mathrm{P} 8, \mathrm{P} 7, \mathrm{P} 6, \mathrm{P} 5, \mathrm{P} 4, \mathrm{P} 3, \mathrm{P} 2, \mathrm{P} 1$ \\
\hline Lannea welwitschii (Hiern) Engl. & Anacardiaceae & Gondo & Kumbi & 20 & 22.98 & 13.06 & $\mathrm{P} 8, \mathrm{P} 7, \mathrm{P} 6, \mathrm{P} 5, \mathrm{P} 2, \mathrm{P} 1$ \\
\hline Macaranga barteri Mull. Arg. & Euphorbiaceae & Mossombal & Mossombal & 21 & 22.37 & 12.77 & $\mathrm{P} 8, \mathrm{P} 7, \mathrm{P} 6, \mathrm{P} 5, \mathrm{P} 4$ \\
\hline Myrianthus arboreus P. Beauv. & Cecropiaceae & Ngata & Ngata & 15 & 22 & 9.1 & P8,P7,P6,P5 \\
\hline Nesogordonia kabingaensis (K.Schum.) Capuron ex R. Germ. & Sterculiaceae & Moduka & Kotibe & 19 & 27.69 & 19.15 & P7,P6,P4,P3,P2,P1 \\
\hline Panda oleosa Pierre & Pandaceae & Mokana & Afan & 13 & 32.24 & 16.77 & $\mathrm{P} 8, \mathrm{P} 7, \mathrm{P} 6, \mathrm{P} 5, \mathrm{P} 3, \mathrm{P} 2$ \\
\hline Petersianthus macrocarpus (P.Beauv.) Liben & Lecythidaceae & Bosso & Essia & 35 & 32.47 & 17.76 & P8,P6,P5,P4,P3,P2,P1 \\
\hline Polyalthia oliveri Engl. & Annonaceae & Motunga & Otungui & 41 & 24.09 & 16.57 & $\mathrm{P} 8, \mathrm{P} 7, \mathrm{P} 6, \mathrm{P} 5, \mathrm{P} 4, \mathrm{P} 3, \mathrm{P} 2, \mathrm{P} 1$ \\
\hline Pycnanthus angolensis (Welw.) Warb. & Myristicaceae & Nkolo & Ilomba & 27 & 23.83 & 14.98 & $\mathrm{P} 8, \mathrm{P} 7, \mathrm{P} 6, \mathrm{P} 5, \mathrm{P} 4, \mathrm{P} 3, \mathrm{P} 2, \mathrm{P} 1$ \\
\hline Staudtia kamerunensis (Warb.) Fouilloy & Myristicaceae & Malonga & Niove & 44 & 18.35 & 11.3 & $\mathrm{P} 8, \mathrm{P} 7, \mathrm{P} 6, \mathrm{P} 5, \mathrm{P} 4, \mathrm{P} 3, \mathrm{P} 2, \mathrm{P} 1$ \\
\hline Sterculia bequaertii De Wild. & Sterculiaceae & Epopoko & Sterculia & 10 & 14.83 & 9.4 & $\mathrm{P} 8, \mathrm{P} 5, \mathrm{P} 4, \mathrm{P} 2, \mathrm{P} 1$ \\
\hline Strombosia grandifolia Hook. f. ex Benth. & Olacaceae & Embongo & Afina & 37 & 23.35 & 15.73 & $\mathrm{P} 8, \mathrm{P} 7, \mathrm{P} 6, \mathrm{P} 5, \mathrm{P} 4, \mathrm{P} 3, \mathrm{P} 2, \mathrm{P} 1$ \\
\hline Strombosia pustulata Oliv. & Olacaceae & Mopipi & Mbazoa jaune & 15 & 40.82 & 21.16 & $\mathrm{P} 8, \mathrm{P} 7, \mathrm{P} 5, \mathrm{P} 3, \mathrm{P} 2, \mathrm{P} 1$ \\
\hline Strombosiopsis tetrandra Engl. & Olacaceae & Ebenge & Edip Mbazoa & 21 & 28.76 & 14.75 & P8,P7,P6,P5,P4,P2 \\
\hline Synsepalum dulcificum (Schumach. \& Thonn.) Daniell & Sapotaceae & Mokenzenze & Mokenzenze & 11 & 21.06 & 10.31 & $\mathrm{P} 8, \mathrm{P} 7, \mathrm{P} 6, \mathrm{P} 5, \mathrm{P} 2, \mathrm{P} 1$ \\
\hline Synsepalum stipulatum (Radlk.) Engl. & Sapotaceae & Bossambela & Bossambela & 11 & 20.98 & 11.75 & $\mathrm{P} 8, \mathrm{P} 6, \mathrm{P} 5, \mathrm{P} 4, \mathrm{P} 3, \mathrm{P} 2, \mathrm{P} 1$ \\
\hline Tetrorchidium didymostemon (Baill) Pax \& K. Hoffm. & Euphorbiaceae & Kopi & $\mathrm{Ka}$ & 27 & 16.21 & 9.2 & $\mathrm{P} 8, \mathrm{P} 7, \mathrm{P} 6, \mathrm{P} 5, \mathrm{P} 4, \mathrm{P} 3, \mathrm{P} 2, \mathrm{P} 1$ \\
\hline Trichilia prieuriana A. Juss. & Meliaceae & Ebakobako & Trichilia & 20 & 22.54 & 10.61 & P8,P7,P6 \\
\hline Turraeanthus africana (Welw. Ex C. DC.) Pellegr. & Meliaceae & Dibembe bembe & Avodire & 20 & 19.6 & 9.9 & $\mathrm{P} 7, \mathrm{P} 6, \mathrm{P} 5, \mathrm{P} 3, \mathrm{P} 2$ \\
\hline
\end{tabular}




\section{Discussion}

The 145 species recorded represent 36 botanical families of which $62.06 \%$ and $37.94 \%$ belong to common species and non-common species respectively for both of sites (Mokelimwaekili and Sombo). The predominance of Sapotaceae, Euphorbiaceae, Meliaceae, Caesalpiniaceae, Sterculiacaee, and Annonaceae in this forest ecosystem indicated the conditions of a tropical Guinean-Congolese and the existence of forest ecological conditions (Raunkier, 1934; Aubreville, 1968). Figure4a shows that it was obvious that the number of species founded in Mokelimwaekili (127 species) were taller than those of Sombo (109 species). While the number of trees recorded in Sombo (733 trees) were taller than those of Mokelimwaekili (607 trees). This could be by fact that Sombo site has been logged during 2002-2003 by Thanry-Congo logging company (authorized concession). So, now Sombo site is in full regeneration period. While the Mokelimwaekili site is an old-growth forest. There is no anthropogenic activity there, the forest is unlogged terra firma forest and no vehicle trail founded. The predominance of Sapotaceae, Euphorbiaceae and Meliaceae in this area was confirmed by STC, (2016). Species distribution in the study sites was mainly influenced by the presence and abundance of rainfall as observed by STC, (2016). Topographic and soil conditions also affected the distribution. The soil at the study sites was of sand-clay ferrallisols (STC, 2016). It was also important to emphasize that the 1340 trees recorded in Ipendja forest during the inventory were taller than the number of trees founded (1100 trees) by Kimpouni et al. (2008) in the Congolese littoral (southern Republic of Congo). The average forest plant species richness in Lesio-louna moist forest (southern Republic of Congo) (Ekoungoulou, 2014) was lower than the species record in this study.

The importance of value index (IVI) of C. mildbraedii, S. kamerunensis and P. oliveri, i.e. $62.06 \%, 30.34 \%$ and $28.27 \%$ respectively, suggested that they were the leading dominant species of this forest. In particular, the first species is typical of the evergreen lowland terra firma forests as mentioned by Fayolle et al., (2016). Evergreen Congo basin forest led by C. mildbraedii was also mentioned in Gabon by Nasi et al., (2012) and in Central Africa Countries by Feldpausch et al., (2011). The floristic variability or the floristic heterogeneity inter-plot was studied. The results showed on the one hand that the sampled plots of inventory belong to the same forest site and on the other hand which there are floristic variabilities due to the variation of the substrate, like had underlined it. The ecology of plant species that make up the backbone of these forests is very poorly known, and therefore their sensitivity to global changes. This lack of knowledge makes it difficult to develop forest-mass adaptation strategies for change. However, the distribution pattern is more distinct for woody and shrub plants than for herbage species along environmental gradient (Liu et al., 2009).

Schluter and Pennell (2017) mentioned that gradients in species richness along spatial and environmental axes have fascinated ecologists, biogeographers, evolutionary biologists and natural historians for centuries. Ecological explanations for these gradients in biodiversity focus on the effects of environmental variables, including productivity, temperature, precipitation and ecological disturbance regimes (the pattern of perturbations in environmental conditions), on species coexistence, whereas evolutionary processes are acknowledged mainly through a historical effect on regional pools of species. The role of variations in speciation rate on biodiversity gradients has been considered occasionally, for example, to explain the greater numbers of species in the tropics compared with temperate regions (the latitudinal biodiversity gradient) (Schluter and Pennell, 2017). The need to manage and conserve tropical forests has never been greater, with a unique challenge to develop strategies that are suitable for sustainable timber production, biodiversity conservation and carbon storage. Tree density significantly contributes to the forest's functional diversity, ecological processes and ecosystem services. Forest ecosystem stability in guineo-congolese region has been confirmed by Kimpouni et al., (2008). The high proportion of trees species confirmed the fact that forest ecosystem in Congo basin tropical zone, especially evergreen lowland moist forests, were sanctuary of biodiversity.

Concerning the structure analysis for ecological management of moist tropical forests, Djomo, (2015) mentioned that interaction between the attributes may change the perception of species diversity that may be obtained only from indexes mentioned above. Analyzing the complexity on biodiversity structure may integrate as much as attributes such as foliage, canopy cover, diameter, diameter distribution, tree height, tree spacing, tree uniformity, and dead wood. Banin et al., (2012) indicated that biodiversity is too broad to measure the entire range of different values or attributes that may affect biodiversity. He suggests refining biodiversity in terms of measurable attributes relevant to the scale and purpose for which it is being assessed which is what was done for this study. Similarity index is another index which may help to better understand the complexity and the difference between distinct forest stands. This index allowed to see that Plot6 and Plot8 in Sombo forests were much similar than the other forest types compared pairwise.

According to Shannon index, there was a high degree of diversity in the two forest sites with Mokelimwaekili the most diversified followed by Sombo (Figure 3). The same pattern was observed in the distribution of the three 
forest types according to Pielou evenness index. Stand complexity showed a different pattern. According to this index, Sombo was the most diversified followed by Mokelimwaekili. At $P=0.05$, one-way ANOVA analysis and Levene test showed no significant effect of the human intervention on the species diversity using Shannon diversity index. Evenness of Jaccard showed significant difference when using Levene test of homogeneity of variances with $P=0.04$, no significant effect with Brown-Forsythe test, and no significant difference with post hoc tests for pairwise comparison. At $P$ level $<0.10$ the least significant difference showed significant difference between Mokelimwaekili and Sombo with $P=0.90$. Considering the floristic diversity of the Northwest Republic of Congo's forests, Koubouana et al. (2016) asserted that the floristic variability or the floristic heterogeneity between-block was studied starting from the factorial analysis of correspondence. These results showed on the one hand that the sampled blocks of inventory belong to the same forest type and in the other hand there are floristic variabilities due to the variation of the substrate, like mentioned. Also, the various blocks belong to the same type of plot highlighted by the indices of similarities. They mentioned that this heterogeneity inter-block is also observed in the tailboards of the same block. Then, the variability of the edaphic factors (composition of the grounds, grounds dewatered and hydromorphic grounds) could explain the richness of the forest of the Mbomo-Kelle forest management unit. In the same study, Koubouana et al. (2016) mentioned that the high values of floristic diversity in Mbomo-Kelle are depending on the abundance of the species respectively Santiria trimera, Scyphocephalium mannii and Plagiostyles africana as also observed by Kimpouni et al. (2008) in the forests of the Youbi in the Southern Republic of Congo's littoral. They were reinforcing the transition forest characteristic of the Mbombo-Kelle, between the forests of the South and North Congo forests.

Regarding the structure and flora tree diversity in a secondary tropical forest of southwest Republic of Congo, Koubouana et al., (2015) asserted that Boubissi forest is in full recovery with low numbers of large trees resulting from previous logging activities. Also, the commissioning of this forest should take into account its history because it has already suffered cuts in the 1960s and 1980s. Logging exploitation of trees must be done following of growth of trees to not compromise regeneration. Koubouana et al., (2015) conducted the similarity analysis of Jaccard and Sorensen. These results show that the Jaccard coefficient ranged from $49 \%$ to $58 \%$ and the Sorensen coefficient varied from $66 \%$ to $74 \%$ in a southwest Republic of Congo's forest. While in this study, we founded in northern Republic of Congo's forest after analysis the Jaccard coefficient of $62 \%$ and Sorensen coefficient of $58 \%$. The results show that there are more common species than non-common species in Ipendja tropical moist forest ecosystem.

\section{Conclusion}

In this study the variation in tree height-diameter between forest plots and among species in northern Republic of Congo was founded. We identified that site2 (Sombo) have more trees than site1 (Mokelimwaekili) by the fact that site2 (Sombo) has been received a selective logging during 2002-2003 and the forest ecosystem is in regeneration period. Celtis mildbraedii Engl., from Ulmaceae also called by Ohia (commercial name) as a pioneer species and is driving the forest ecosystem dynamic. This species by his abundance is leading the forest ecosystem movement. After analysis the results show that the number of species varied from one plot to others. Also, the species from Passifloraceae, Pandaceae, Tiliaceae, Vochysiaceae, Huaceae, Bombacaceae, Bignoniaceae, Rutaceae were represented only by one individual in study sites. This low proportion of relative frequency in Ipendja evergreen lowland moist forest could be by the fact that some edaphic and climatic conditions are no favourable for these species. Finally, knowing Ipendja floristic richness by this study, Ipendja evergreen tropical forest ecosystem is very important and could contribute to the global environmental protection and support the reducing emissions from deforestation and forest degradation, and forest conservation, sustainable management of forest, and enhancement of forest carbon stocks $\left(\mathrm{REDD}^{+}\right)$guidelines.

\section{Conflict of Interests}

The authors declare that there is no conflict of interests regarding the publication of this paper.

\section{Acknowledgments}

Authors greatly acknowledge Chinese government under the direction of China Scholarship Council (www.csc.edu.cn) and Beijing Forestry University (www.bjfu.edu.cn) for supporting this research. We would like to thank Georges Claver Boundzanga from Republic of Congo's Ministry of Forestry Economy and Sustainable Development and CN-REDD Project for providing facilities for field measurements in UFA Ipendja (Likouala department, Northern Republic of Congo). Field measurements were also facilitated by Thanry-Congo logging company (STC). We thank two anonymous reviewers for constructive comments on the early version of this paper. 


\section{References}

ANAC. (2016). Rapport annuel de l'Agence Nationale de l'Aviation Civile. Agence Nationale de l'Aviation Civile (ANAC). Brazzaville, Congo.

Aubreville, A. (1968). Les Caesalpinioidées de la flore camerouno-congolaise. Considérations taxonomiques, chorologiques, écologiques, historiques et évolutives. Adansonia, 8(2), 147-175.

Banin, L., Feldpausch, T. R., Phillips, O. L., Baker, T. R., Lloyd, J., Affum-Baffoe, K., ... Lewis, S. L. (2012). What controls forest architecture? Testing environmental, structural and floristic drivers. Global Ecology and Biogeography, 21(12), 1179-1190.

Curtis, J. T. (1959). The vegetation of Wisconsin. In: An ordination of plant communities. University of Wisconsin Press, Madison, Wisconsin.

Djomo, A. N. (2015). A Structure Analysis for Ecological Management of Moist Tropical Forests. International Journal of Forestry Research, 2015(2015), 1-12.

Ekoungoulou, R., Liu, X. D., Ifo, S. A., Loumeto, J. J., \& Folega, F. (2014a). Carbon stock estimation in secondary forest and gallery forest of Congo using allometric equations. International Journal of Scientific \& Technology Research, 3(3), 465-474.

Ekoungoulou, R., Liu, X. D., Loumeto, J. J., Ifo, S. A., Bocko, Y. E., Koula, F. E., \& Niu, S. K. (2014b). Tree Allometry in Tropical Forest of Congo for Carbon Stocks Estimation in Above-Ground Biomass. Open Journal of Forestry, 4(5), 481-491.

Ekoungoulou, R. (2014). Carbon Stocks Evaluation in Tropical Forest, Congo. Carbon Stocks in Forest Ecosystems. Lambert Academic Publishing. Saarbrucken, Germany.

Ekoungoulou, R., Niu, S.K., Loumeto, J. J., Ifo, S. A., Bocko, Y. E., Mikieleko, F. E. K., ... Liu, X.D. (2015). Evaluating the carbon stock in above-and below-ground biomass in a moist central African forest. Applied Ecology and Environmental Sciences, 3(2), 51-59.

Ekoungoulou, R., Folega, F., Mukete, B., Ifo, A. S., Liu, X. D., Loumeto, J. J., \& Niu S. K. (2017). Floristic Diversity and Structural Analysis of Trees in a Central African Forest. Brazilian Journal of Botany (In press).

Ernst, C., Mayaux, P., Verhegghen, A., Bodart, C., Christophe, M., \& Defourny, P. (2013). National Forest Cover Change in Congo Basin: Deforestation, reforestation, degradation and regeneration for the years 1990, 2000 and 2005. Global Change Biology, 19(4), 1173-1187.

FAO. (2016). State of the World's Forests. Forests and agriculture: land-use challenges and opportunities. Food and Agriculture Organization of the United Nations. Rome, Italy.

Fayolle, A., Ouedraogo, D. Y, Ligot, G., Daïnou, K., Bourland, N., Tekam P., \& Doucet, J. L. (2015). Differential Performance between Two Timber Species in Forest Logging Gaps and in Plantations in Central Africa. Forests, 6(2), 380-394.

Fayolle, A., Panzou, G. J. L., Drouet, T., Swaine, M. D., Bauwens, S., Vleminckx, J., Biwole, A., Lejeune, P., \& Doucet, J. L. (2016). Taller trees, denser stands and greater biomass in semi-deciduous than in evergreen lowland central African forests. Forest Ecology and Management, 374, 42-50.

Fedor, P. J., \& Spellerberg, I. F. (2013). Shannon-Wiener Index. Reference Module. Earth Systems Environmental Sciences, 1, 1-4.

Feldpausch, T. R., Banin, L., Phillips, O. L., Baker, T. R., Lewis, S. L., Quesada, C. A., ... Lloyd, J. (2011). Height-diameter allometry of tropical forest trees. Biogeosciences, 8, 1081-1106.

Folega, F., Zhao, X. H, Zhang, C. Y., Wala, K., \& Akpagana, K. (2010). Ecological and numerical analyses of plant communities of the most conserved protected area in north Togo. International Journal of Biodiversity and Conservation, 2(11), 359-369.

Folega, F., Kperkouma, W., Zhang, C. Y., Zhao, X. H., \& Koffi, A. (2011). Woody vegetation of protected areas in Northern Togo. Case of Barkoissi, Galangashi and Oti-Keran: Ecological and Structure Analyses of Plant Communities. Forestry Study in China, 13(1), 23-35.

Folega, F., Zhang, C. Y, Woegan, Y. A., Wala, K., Dourma, M., Batawila, K., Seburanga, J. L., Zhao, X. H., \& Akpagana, K. (2014). Structure and Ecology of Forest Plant Community in Togo. Journal of Tropical Forest Science, 26(2), 225-239. 
Kimpouni, V., Loumeto, J. J., \& Mizingou, J. (2008). Diversité floristique du faciès forestier à Aucoumea klaineana (Okoumé) du littoral congolais. Acta Botanica Gallica : Botany Letters, 155(3), 323-334.

Koubouana, F., Ifo, S. A., Moutsambote, J. M., Banzouzi, R. R. F., Akobe, A., Ikama, C. O., „, Mbemba, M. (2015). Structure and Flora Tree Biodiversity in Congo Basin: Case of a Secondary Tropical Forest in Southwest of Congo-Brazzaville. Research in Plant Sciences, 3(3), 49-60.

Koubouana, F., Ifo, S. A., Moutsambote, J. M., \& Mondzali-Lenguiya, R. (2016). Floristic Diversity of Forests of the Northwest Republic of the Congo. Open Journal of Forestry, 6(5), 386-403.

Legendre, P. (2014). Interpreting the replacement and richness difference components of beta diversity. Global Ecology and Biogeography, 23, 1324-1334.

Lewis, S. L., Sonke, B., Sunderland, T., Begne, S. K., Lopez-Gonzalez, G., van der Heijden, G. M. F., ... Bastin, J. F., (2013). Aboveground biomass and structure of 260 African tropical forests. Philosophical Transactions of the Royal Society B: Biological Sciences, 368(1625), 1896-1934.

Lewis, S. L, Edwards, D. P., \& Galbraith, D. (2015). Increasing human dominance of tropical forests. Science, $349(6250), 827-832$.

Lopez-Gonzalez, G., Lewis, S. L., Burkitt, M., \& Phillips, O. L. (2011). ForestPlots.net: a web application and research tool to manage and analyse tropical forest plot data. Journal of Vegetation Science, 22, 610-613.

Liu, B., Zhao, W. Z, Wen, Z. J., Teng, J. R., \& Li, X. H. (2009). Floristic Characteristics and Biodiversity Patterns in the Baishuijiang River Basin, China. Environmental Management, 44, 73-83.

Nasi, R., Billand, A., \& Vanvliet, N. (2012). Managing for timber and biodiversity in the Congo Basin. Forest Ecology and Management, 268, 103-111.

Ouedraogo, D. Y., Beina, D., Picard, N., Mortier, F., Baya, F., \& Gourlet-Fleury S. (2011). Thinning after selective logging facilitates floristic composition recovery in a tropical rain forest of Central Africa. Forest Ecology and Management, 262, 2176-2186.

Raunkier, C. (1934). The life forms of plants and statistical plant geography. Oxford University Press, London, UK.

Schluter, D., \& Pennell, M. W. (2017). Speciation gradients and the distribution of biodiversity. Nature, 546, 48-55.

Spellerberg, I. F., \& Fedor, P. J. (2003). A tribute to Claude Shannon (1916-2001) and a plea for more rigorous use of species richness, species diversity and the Shannon-Wiener Index. Global Ecology and Biogeography, 12(3), 177-179.

STC. (2016). Rapport annuel de la Societé Thanry-Congo. Vicwood Group. Ipendja, Congo.

Supriya-Devi, L., \& Yadava, P. S. (2006). Floristic diversity assessment and vegetation analysis of tropical semi evergreen forest of Manipur, north east India. Tropical Ecology, 47(1), 89-98.

Thomas, S. C., Martin, A. R., \& Mycroft, E. E. (2015). Tropical trees in a wind-exposed island ecosystem: height-diameter allometry and size at onset of maturity. Journal of Ecology, 103(3), 594-605.

White, F. (1983). The vegetation of Africa: a descriptive memoir to accompany the UNESCO/AETFAT/UNSO vegetation map of Africa. ORSTOM-UNESCO, Paris, France.

\section{Copyrights}

Copyright for this article is retained by the author(s), with first publication rights granted to the journal.

This is an open-access article distributed under the terms and conditions of the Creative Commons Attribution license (http://creativecommons.org/licenses/by/4.0/). 